\title{
Open Access Publishing as a Para-Academic Proposition: Besides OA as Labour Relation
}

\section{Paul Boshears}

The European Graduate School, Saas-Fee, Switzerland, paul.boshears@egs.edu, www.continentcontinent.cc

\begin{abstract}
In this commentary, I ask what is meant by the phrase Open Access (OA)? If OA publishing has emancipatory potential for the publics that are thought to benefit from the practice, why is there so much business as usual? Para-academic practices are about affirming scholarship as a symptom and creating a common good, creating a public knowledge that is a knowledgeable public. It is because $\mathrm{OA}$ shares this concern for publics that para-academic practices include OA publishing. By debating the merits of, experimenting with, and invigorating our understanding of OA I believe para-academic practices become more apparently necessary because ultimately OA, like Academia, is haunted by the figure of the public as an already-formed thing.
\end{abstract}

Keywords: Open Access, Para-Academia, Creative Commons Licensing

Open Access publishing isn't a disruptive technology, it is a labour relation. The initial intentions of Open Access (OA) activists included making universally available scholarly research information such that any article would be available - minimally as its "pre-print" form - to readers for whom the version of record was not available (Okerson and O'Donnell 1995). Since those early years of OA agitating, there has been an on-going debate internally among proponents and externally among relevant stakeholders (including traditional publishers, academics, university administrations, librarians, policy makers, etc.) with mixed results as to whether the emphasis will be upon making research (frequently funded by tax payers) more open or more accessible. To date it would appear we have arrived no closer to understanding what we mean by openness (Rosenberg 2009 Grubb and Easterbrook 2011), nor resolved for whom the products resulting from this labour will be made accessible or what manifest good this access issues (Isis 2013, Poynder and Babini 2013). So why, if our goal is to clarify the role of OA in future academic practices, should I want to further muddy the waters by introducing another poorly-understood phrase like "para-academic?" It is my suggestion that these two phrases (both of questionable utility, and perhaps obsolete at inception) have developed in response to mutually-influencing material conditions and I suggest that the para-academic position affords the space necessary for OA to make good on its emancipatory claims.

My use of the phrase "para-academic" was initiated by Eileen A. Joy and Nicola Masciandaro of the BABEL Working Group and founders of the para-academic press Punctum Books. I learned the phrase after being invited to speak on a panel they were organizing with the Hollow Earth Society and the Public School New York. For Masciandaro and Joy the term:

captures the multivalent sense of something that fulfills and/or frustrates the academic from a position of intimate exteriority [....] The para-academic embodies an unofficial excess or extension of the academic that helps, threatens, supports, mocks (par-ody), perfects and/or calls it into question simply by existing next to it. (Joy and Masciandaro, 2012).

Elsewhere I've sought to elaborate and further add to what the para-academic proposition might entail, including para-academic publishing as an act of public-making (Boshears 2014). In short, para-academic practices are about affirming scholarship as a symptom (Cohen 
2010) and creating a common good, a public knowledge that is a knowledgeable public. It is because $O A$ shares this concern for publics that para-academic practices include $O A$ publishing. By debating the merits of, experimenting with, and invigorating our understanding of OA I believe para-academic practices become more apparently necessary because ultimately OA, like Academia, is haunted by the figure of the public as an already-formed thing. But before going to deeply into that, there is still the need to examine what $O A$ publishing is.

\section{What Do We Mean by Open? What Do We Mean by Access?}

There are at least two ways of understanding OA. In the initial two decades of OA activism there arose a desire to liberate data and information among a class of knowledge workers reacting to the shifting conditions of the modes of production. This reactionary predisposition is a residue of the cyber-libertarian slogan "information wants to be free", which lead to the distinction between gratis and libre. Rather awkwardly and with minimal clarification for policy making, this Open Source (software) distinction has been "ported" onto OA publishing (Suber 2008). Here we begin to see the first problem with OA publishing and an affinity with the para-academic proposition because Open Source software is itself primarily a parasitical arrangement between existing intellectual property laws and the community of software engineers that volunteer their services. Open Source software has at least two ulterior motives guiding its production, as either an act of pro bono service to the community (this granting the accomplished coder accolades among their community), or as a means of gaining experience akin to someone accepting an unpaid internship so that they can be more competitive while seeking future software development work. This antinomious relationship is well-illustrated when we consider the most popular Open Source license at work today, the GNU General Public License (GPL) which aggressively works to address both contract and copyright law, purporting to bind all subsequent users of the software to the terms of the original license. As Wagner (2003) points out, there are dozens of similar Open Source licensing arrangements proliferating today contain a number of significant restrictions, such as:

- a requirement that any software containing licensed code be distributed only under the same license;

- a requirement that all changes to licensed code be noted and released to the public;

- a prohibition on "mixing" code subject to varying licenses;

- a requirement that patent claims be waived;

- a requirement that credit be given to original sources of the code;

- a requirement that all changes to the code be licensed back to the original source; and termination-of-license clauses implying that the original source can assert infringement claims under certain conditions (Wagner, 1030).

With Creative Commons licensing we see language very similar to the above deployed as well. Some might argue that there is also a similar presupposition operating in both Open Source and Creative Commons licensing, that every person making things creates with the belief that 1) these creations are property and 2) access to legal recourse is equitably distributed across societies thereby protecting this presumed property relationship (Economic Observatory of the University of Openness 2004). In spite of the rhetoric of openness, it is clear there is a very tightly controlled arrangement between parties that is reliant upon (as a parasite to its host) already-existing property laws and policing powers to enforce this licensing.

Among the arguments for promoting more OA publishing there is a tacit implication that $\mathrm{OA}$ is the morally correct thing to do because OA makes knowledge available to anyone, "information wants to be free," and the Internet reduces the distribution costs of this information to close to nothing. But of course "the Internet" isn't free: it is subject to the same material forces reproducing the already existing material inequalities across the globe 
(Gladieux and Swail 1999; Jung, Qiu and Kim 2001). What OA publishing so far seems to have done is to cement English as the only language that matters in academic affairs (Graham, Hale and Stephens 2011; Sipp 2013), a situation Cameron Neylon has described as, "enabling read access while blocking write access" (Poynder and Neylon 2013). Furthermore so-called Gold Open Access, where authors pay article processing charges, has created "a gold rush environment" (Poynder and Babini 2013) in which those elite institutions and affluent actors ignore the potential for scholarly communication to be free from market forces. While there are Gold Open Access journals that have reduced- or nofees for junior scholars and those scholars from "low income" countries (Frontiers 2013), there is little reason to doubt that the scholarly publishing industry will thrive with this new author-pays-to-publish business model and peer-review itself is modified to favour highvolume publishing (Van Noorden 2013, Esposito 2013).

The OA debate presupposes that the publics benefiting from OA publishing are actually a fairly exclusive lot: these publics have access to the Internet, they are sighted, they can read and they read English fluently, and they are in life circumstances such that the consumption of the latest knowledge from the United States and the United Kingdom, the largest producers of academic knowledge (Graham, Hale and Stephens 2011) is valuable. Given these parameters, no matter how pervasively distributed OA publications might be, saying that this information is accessible seems myopic. Or perhaps the word "Access" in OA is a code word for a particular community?

\section{Publication as the Process of Public-Making}

Although I put forward these criticisms of Open Access and Creative Commons licensing, I am an editor of what Fuchs and Sandoval (2013) might call a Diamond Access journal, continent., and I intend to continue to do so. My purpose here is to point out certain elements of how academic work is being done so as to underscore why the para-academic proposition is at times a preferable mode of operating in Academia. We are living in and engendering dramatic changes to how the work of Academia is done. These are the last days of "the last professors" (Donoghue 2008). It is in response to these shifting parameters that the paraacademic proposition is developing. OA publishing is an import element of the paraacademic public in so far as $O A$ is a practice that engenders a public pursuing a common good that is alongside the already-existing forms of ownership within knowledge-producing industries. And the para-academic proposition is a profoundly useless proposition.

But this is uselessness as a tactical engagement with the life of the mind. As Eileen Joy put it so well, "There is no good reason to put a limit to thought within the setting of the university" (Joy 2013, 34). In contrast to Joy's call for errancy in publishing is the more disciplined approach that Kent Anderson (2010) embodies when he states,

\footnotetext{
If being published in a journal no longer immediately carries the imprimatur of having cleared a high bar of scrutiny, then the form itself is at risk. Journals could become merely directories of research reports. And publishers who are truly setting standards should take notice of the risk the drift toward directories poses.
}

To be fair to Anderson, he's not arguing against OA publishing but rather against the rise of a class of unscrupulous OA publisher that Anderson believes exploits academics' economic need to publish the results of their work. In Anderson's view the traditional subscriber-pays model is based on the journal's ability to exploit for profit a public's trust in the quality of a journal's taste. It's an honest dollar, I suppose. Before my argument devolves too far, from this supposition - that a journal does it's job well when it maintains certain standards (said another way, polices certain disciplinary boundaries) - we are left to wonder how change happens within academic publishing and whether this parallels changes within Academia. Karl Popper and Thomas Kuhn present contrasting views to which Casey Brienza (2013) adds a third avenue that highlights just how financialization of knowledge production has 
become.

Eisenberg (1989), in her exploration of the necessity for experimental use clauses within copyright law, contrasts Karl Popper's presentation of scientific advancement with Thomas Kuhn's paradigmatic view. According to Popper's view, scientists are eternally vigilant and are in a constant state of "falsification" by comparing theory-based predictions with empirical results. In Kuhn's account, the scientific community practices "normal science" most of the time, conducting experiments that assume the dominant paradigms of the field at present. In this regime of normal science, the activity is to reconcile empirical observations with the theories to which they are already intellectually committed. But, as Kuhn's argument recognizes, there are periods of "scientific revolution" wherein the dominant paradigm falls away and new ideas about the nature of everything are contested and cemented. This is the inexorable result of the anomalous results that will be found while conducting "normal science", and thus the need for new models to explain the outliers. Given that there is this conceptual competition inbuilt to the process of paradigm generation, Eisenberg makes the case that there is a need for free access to prior research during both the periods of "normal science" and in the periods of crisis. In the early stages of a field's paradigm search the lack of such access may mean that the systematic gathering of data is impeded and thus the practical problems faced by applied research act as substitutes for an actual explanatory paradigm. On the other side of the "crisis" (I qualify the word since it would appear that this is not at all a crisis, but a latent element of how the production process normally functions) that "normal science" induces, those periods when, Eisenberg (1989) writes,

new theories compete with old theories for the allegiance of a scientific community, free access to prior discoveries may be essential in order to put the proponents of new theories in a position to challenge their predecessors and offer alternative explanations for previous observations.

[....] Free access to prior discoveries may thus be critical in allowing newcomers to the field to challenge the achievements of more established figures (153).

Against this vision of academics themselves as the agents policing and revolting against one another in the pursuit of knowledge production, Brienza's spirited defence of academic publishers introduces a third way.

To the Popper/Kuhn dichotomy Brienza introduces the salubrious side effect that economies of scale in academic publishing have had for academics. With the new paradigms in thinking generating new fields of inquiry, there is the constant need for academics to justify why the public should fund their research. Given that publication has been the principle means of demonstrating one's academic productivity (rather than number of students taught, or committee meetings convened, say) a symbiotic relationship between Academia and academic publishers has flourished. Were it not for this expanding universe of publications and new fields of inquiry, Brienza argues, "had publishers relied solely upon public funding, it's likely that the entire academic system, which depends upon the credentialing of peerreviewed publishing for employment, tenure, and promotion, would have collapsed long ago" (518). It would seem that Brienza and Anderson are both warning against the deprofessionalization of publishing that OA publishing might encourage. They seem to tacitly agree with Ramsay's (2010) argument, that the number of publications an academic has is the grossest metric for tenure assessment. It's not the only metric, but these publications can help establish a floor from which to begin comparing tenure candidates. Against this outsourcing of academic work, Ramsay argues a para-academic tactic, "to present our colleagues with as many inscrutable objects as possible". What publishers offer is the capacity to develop work, to assess the value of an academic's contribution to an on-going conversation in a field and the para-academic publisher is also concerned with creating publics that result from the circulation of these objects. When we talk about promoting Open Access publications, the para-academic position is that Open Access must be about the generation of a common good. 
A public is the result of the circulation texts (Warner, 2002), a text being understood in the broadest way possible to encompass reading as a technique for consuming manifold media. But this circulation of texts is not only the mechanism by which subjects are interpellated it is also the mechanism by which the common good is established. In the Anglo-Saxon legal tradition a subjective promise becomes an objective legal obligation when there is the circulation of a text, called a material consideration (Pietz 2002), between two parties. This transformation from, essentially, private words between two people into a communal concern is at the heart of what it means to live in a society. Being true to our words means valuing the listener's presence to the utterance and investing in our mutual situation. When people make good on what they promise, society itself appreciates in value, the immaterial dividends are distributed informally in the sense of trust one has (distinct from the "safety" of order that policing promises). The publics established in these moments of social consummation - the making good on our words - are not only autonomous units bound by external contracts (it can be simply that), they are also, potentially, sites of the expression of mutual determination that being in a communicating community latently promises. This is the para-academic proposition in the debate about the future of Open Access publishing. In the absence of an understanding that no amount of openness will make communications accessible (in the sense that access is a means of finding common ground), OA publishing is doomed to becoming a Rube Goldberg Machine parody of itself: privating (Fitzpatrick 2010) rather than publishing.

\section{References}

Anderson, Kent. 2010. PLoS' Squandered Opportunity - Their Problems with the Path of Resistance. The Scholarly Kitchen. Accessed 11/23/2013. http://scholarlykitchen.sspnet.org/2010/04/27/plossquandered-opportunity-the-problem-with-pursuing-the-path-of-least-resistancel

Boshears, Paul. 2014. Para-Academic Publishing as Public-Making. In The Para-Academic Handbook, edited by Alex Wardrop and Deborah Withers. London: HammerOn Press.

Brienza, Casey. 2013. What Do Publishers Know? tripleC: Communication, Capitalism \& Critique 11 (2): 515-520.

Cohen, Dan. 2010. Open Access Publishing and Scholarly Values. In Hacking the Academy, edited by Dan Cohen and Tom Scheinfeldt, 39-47. Ann Arbor: University of Michigan Press.

Donoghue, Frank. 2008. The Last Professors: The Corporate University and the Fate of the Humanities. New York: Fordham University Press.

Economic Observatory of the University of Openess. 2004. Commercial Commons. Mute. Accessed 11/23/2013. http://www.metamute.org/editorial/articles/commercial-commons

Eisenberg, Rebecca S. 1989. Patents and the Progress of Science: Exclusive Rights and Experimental Use. The University of Chicago Law Review 56 (3): 1017-1086.

Esposito, Joseph. 2013. How PLoS ONE Can Have It All. The Scholarly Kitchen. Accessed 12/3/2013. http://scholarlykitchen.sspnet.org/2013/12/03/how-plos-one-can-have-it-all

Fitzpatrick, Kathleen. 2010. On Open Access Publishing. Society for Critical Exchange. Accessed 11/23/2013. http://societyforcriticalexchange.org/blog/blog3.php/2010/01/15/on-open-accesspublishing

Frontiers. 2013. Open Access \& Publishing Fees. Accessed 11/23/2013. http://www.frontiersin.org/about/PublishingFees

Fuchs, Christian and Marisol Sandoval. 2013. The Diamond Model of Open Access Publishing: Why Policy Makers, Scholars, Universities, Libraries, Labour Unions and the Publishing World Need to Take Non-Commercial, Non-Profit Open Access Serious. tripleC: Communication, Capitalism \& Critique 11 (2): 428-443.

Gladieux, Lawrence E. and Watson Scott Swail. 1999. The Internet: New Engine of Inequality? Washington, DC: The College Board. Accessed 11/23/2013. https://net.educause.edu/ir/library/html/edu9949/edu9949.html

Graham, M., Scott A. Hale, and Monica Stephens. 2011. Geographies of the World's Knowledge. London: Convoco! Edition.

Grubb, Alicia M. and Steve M. Easterbrook. 2011. On the Lack of Consensus over the Meaning of Openness: An Empirical Study. PLoS ONE. Accessed 11/23/2013. http://www.plosone.org/article/info\%253Adoi\%252F10.1371\%252Fjournal.pone.0023420

Isis the Scientist. 2013. The Morality of Open Access vs Increasing Diversity. Accessed 11/23/2013. http://isisthescientist.com/2013/08/28/the-morality-of-open-access-vs-increasing-diversity 
Joy, Eileen. 2013. Weird Reading. Speculations: A Journal of Speculative Realism 4: 28-34. Accessed 11/23/2013. https://speculations.squarespace.com/storage/Joy Weird\%20Reading Speculations IV.pdf

Joy, Eileen and Nicola Masciandaro. 2012. The Para-Academia Series: Panel Discussion on Para Academic Publishing \& Book Party. The Public School New York. Accessed on 11/23/2013. http://thepublicschool.org/node/28961

Jung, Joo-Young, Jack Linchuan Qiu and Yong-Chan Kim. 2001. Internet Connectedness and Inequality: Beyond the "Divide". Communication Research 28 (4): 507-535.

Okerson, Ann and James O'Donnell, eds. 1995 Scholarly Journals at the Crossroads: A Subversive Proposal for Electronic Publishing. Washington, D.C.: Association of Research Libraries.

Pietz, William. 2002. Material Considerations: On the Historical Forensics of Contract. Theory, Culture \& Society 19 (5/6): 35-50.

Poynder, Richard and Dominique Babini. 2013. Dominique Babini on the State of Open Access: Where Are We, What Still Needs To Be Done? Accessed 11/23/2013. http://poynder.blogspot.co.uk/2013/07/dominique-babini-on-state-of-open.html

Poynder, Richard and Cameron Neylon. 2013. Public Library of Science's Cameron Neylon on the State of Open Access: Where Are We, What Still Needs To Be Done? Accessed 11/23/2013. http://poynder.blogspot.co.uk/2013/09/public-library-of-sciences-cameron.html

Ramsay, Stephen. 2010. Open Access Publishing and Scholarly Values (Part Two). In Hacking the Academy, edited by Dan Cohen and Tom Scheinfeldt., 39-47 Ann Arbor: University of Michigan Press.

Rosenberg, Jonathan. 2009. The Meaning of Open. Accessed 11/23/2013. http://googleblog.blogspot.com/2009/12/meaning-of-open.html

Sipp, Douglas. 2013. Advocacy: How to Hasten Open Access. Nature 495: 442-443. Accessed 11/23/2013. http://www.nature.com/nature/journal/v495/n7442/full/495442a.html\#douglas-sipp

Suber, Peter. 2008. Welcome to the SPARC Open Access Newsletter, issue \#124. Accessed 11/23/2013. http://legacy.earlham.edu/ peters/fos/newsletter/08-02-08.htm\#gratis-libre

Van Noorden, Richard. 2013. PLoS Profits Prompt Revamp. Nature News \& Comment. Accessed 11/23/2013. http://www.nature.com/news/plos-profits-prompt-revamp-1.14205

Wagner, R. Polk. 2003. Information Wants to Be Free: Intellectual Property and the Mythologies of Control. Columbia Law Review 103: 995-1034.

Warner, Michael. 2002. Publics and Counterpublics. Public Culture 14 (1): 49-90.

\section{About the Author}

Paul Boshears

Is a PhD candidate (advisor Avital Ronell) at the European Graduate School in Switzerland where he has studied with Giorgio Agamben, Judith Butler, Jacques Rancière, and Slavoj Žižek. His research and studies have been conducted in East Asia, West Africa, Europe, North America, and the Deep South. Paul is Co-Editor of the journal continent. and sits on the Advisory Board of the Rhetoric and Media journal, Itineration. Paul's work has appeared in high impact scholarly journals across diverse disciplines as well arts publications and has received several national and international design awards. 